$$
\begin{array}{ll}
\text { УДК } & 316.4 .063 .5 \\
& 005.334: 334.72
\end{array}
$$

COBISS.SR-ID 513526965

https://doi.org/10.18485/fb_godisnjak.2019.4

\title{
РЕГРЕСИЈА У ГРУПИ И ОРГАНИЗАЦИЈИ И КОРПОРАТИВНА БЕЗБЕДНОСТ
}

\author{
Проф. др Борис Кордић* \\ Универзитет у Београду, Факултет безбедности
}

* kordic@fb.bg.ac.rs 



\section{РЕГРЕСИЈА У ГРУПИ И ОРГАНИЗАЦИЈИ И КОРПОРАТИВНА БЕЗБЕДНОСТ}

Сажетак: У овом раgу се размат̄ра ӣојава реїресије у їруйи и орїанизацији уйотиребом Бионове тиеорије о іруйама, која разликује ява обли-

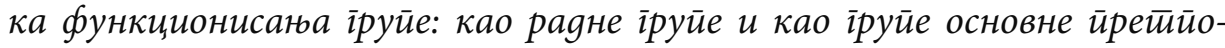

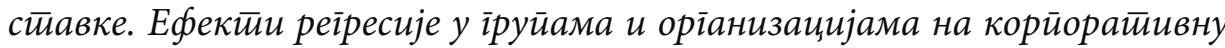
безбеуности су веома неіатиини и стиоіа је йознаване ове йојаве важно за йравовремено ирреиознаване и сирречаване юеноі развоја, као и за иниервенисанье у йоновно улаїане у функиионисане раяне іруиее. Ширим

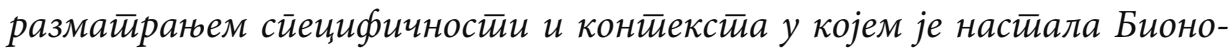

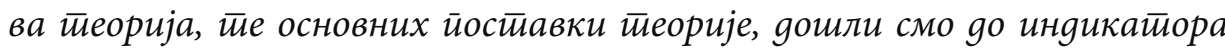
који разликују навеgене облике функиионисања ірруие, а тио су: сараgюа,

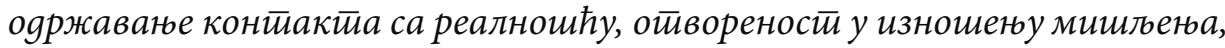
мотиивачија усмерена на осиввареюе заgаикка. Уколико су набројани ин-

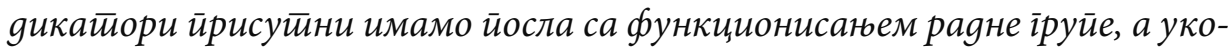

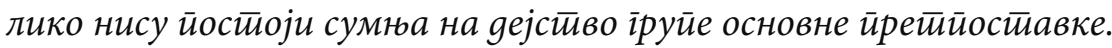

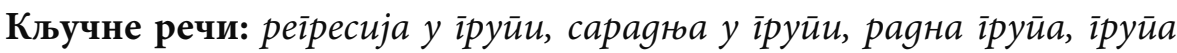
основне йретийостиявке. 


\section{Увод}

Корпоративна безбедност се појављује као основни облик безбедности у XXI веку, у тој мери да се може очекивати да ће све што треба да знамо, што се питамо, чега се плашимо или планирамо о безбедности, бити присутно у области корпоративне безбедности (Walby \& Lippert, 2014). Доступност литературе из корпоративне безбедности није у складу са значајем који дата област има, а посебно недостаје литература уџбеничког типа, што указује на недостатак систематизације. Последица тога је да су и дефиниције корпоративне безбедности сувише опширне и нејасне. Једна од дефиниција истиче да се ради о практичном сектору који пружа услуге унутрашње безбедности и функционише у оквиру јавних или приватних предузећа како би се заштитила вредна имовина (Brooks, 2013).

У последњој фази развоја корпоративне безбедности, названој „ера тоталне заштите имовине“, проширило се поље деловања корпоративне безбедности, тако да било која акција која може бити штетна по организацију и захтева праћење постаје предмет пажње (Dalton, 2003). У овом раду желимо да укажемо на значај људских ресурса за корпоративну безбедност, са фокусом на групној динамици и појави регресије у групи и организацији.

Значајан допринос разумевању групне динамике дала је социјална психологија, а посебну визуру разумевања несвесне динамике пружају психоаналитичка тумачења. То ће представљати теоријски оквир за приступ разумевању појаве регресије у групама и организацијама. У којој мери су емоције значајне у групној динамици, говори тумачење појаве „експлозије управљања ризицима“ раширеним анксиозностима услед неспособности да се носимо са неизвесностима (Power, 2007). Ово је до те мере присутно да се корпоративне несреће посматрају као знак губитка контроле у свету. Чињеница јесте да живимо у времену промена које захтева стално прилагођавање и уноси осећање нестабилности. Компаније излазе на крај са променама све већом употребом тимског рада и сарадње. Запослени данас, према неким извештајима, проводе $50 \%$ више времена у сарадњи него пре двадесет година (Cross, Rebele, \& Grant, 2016).

За сарадњу и рад у тиму од посебног значаја је могућност слободног изражавања свог мишљења. Истраживања показују да се само 3 од 10 запослених изражено слажу са тврдњом да се њихова мишљења уважавају на послу (Gallup, 2017). Прорачун је направљен за ситуацију у којој би 6 од 10 запослених имали изражено слагање, према којем би то било праћено 27\% мањим напуштањем посла, $40 \%$ смањењем инцидената на пољу сигурности и $12 \%$ повећањем у продуктивности. Да би запосле- 
ни могли да слободно исказују своје мишљење, неопходно је да постоји квалитет психолошке сигурности на радном месту (Edmondson, 2018). То значи да група којој запослени припадају прихвата грешке, упућује критике, али, пре свега, тражи искрено саопштавање мишљења.

Психолошка сигурност на радном месту је квалитет групе а не појединца, јер појединци се често руководе међуљудским страховима у свом понашању. Један од јачих социјалних мотива је потреба да се прикажемо у бољем светлу, а отворено изношење мишљења може да нас учини рањивим на критику и повећава шансе да се покажемо као некомпетентни и да се осетимо одбачено. Међутим, иако суздржавање од изношења мишљења помаже што се тиче личне сигурности, оно ипак води осећању незадовољства и смањује радни учинак, тако да је ефекат ћутања ризичан за групу и организацију у целини (Edmondson, 2018).

Дакле, за успешно функционисање људи у организацији, од досад наведених квалитета људског капитала потребни су: сарадња, тимски рад, те психолошка сигурност на радном месту која омогућава слободно изражавање мишљења. Специфичан угао гледања на групну динамику који желимо да истакнемо је перспектива групе као целине, а не групе као збира појединаца. Приликом разматрања међусобног утицаја између групе и појединца, нас занимају облици групне динамике који су независни од индивидуалних карактеристика чланова, већ показују утицај на све и кроз све чланове групе.

Друга специфичност нашег приступа произилази из психоаналитичких тумачења и индиректног утицаја концепта менталног здравља на посматрање групне динамике. У том смислу се може разликовати зрело и, условно речено, незрело функционисање групе и организације. Настојаћемо да избегнемо овакав начин посматрања у даљем тексту, али је неопходно на почетку разјаснити и ову врсту теоријског ослонца ради историјске перспективе у развоју теорија групне динамике, као и ради честе употребе појма зрелости и групног функционисања у литератури. Феномен регресије у групи и организацији спада у незрело функционисање групе.

\section{Прва тумачења регресије у групи и организацији}

Роџер Шапиро (Roger L. Shapiro) у свом тексту Психоаналитиччке $\bar{u} е-$ орије і̄pуйa и оріанизација наводи да је „психоанализа дала јединствени допринос теорији група захваљујући својој способности да концептуализује несвесне процесе код чланова групе, као и концептуализацији активације, појаве, и последица регресије у групи“ (Shapiro, 1991, p. 760). 
Прво психоаналитичко тумачење групе и групне регресије налазимо у Фројдовом делу Психолоіија іруйе и анализа еі̄a (Freud, 1921). Вероватно је интересовање за групну регресију било подстакнуто претечама социјалне психологије присутним у етно-психологији, а посебно у психологији масе, чији је најзначајнији представник Густав ле Бон (Gustave Le Bon). Интерес је тада био усмерен на тумачење абнормалног понашања иначе нормалних људи под утицајем масе. Објашњења су се тражила у феноменима сугестије, имитације и менталне заразе (Kordić, 2017).

Фројд је проширио употребу структуралног модела психе (ид, его, суперего) са разумевања индивидуе на разумевање групе (Schneider, 2015). Стога је његов приступ психоаналитичком разумевању социјалних појава водио порицању разлике између индивидуе и групе, те сужавању истраживачког поља на несвесно појединца (Szykierski, 2010). Основно тумачење које је Фројд понудио о динамици групе је да се она заснива на либидиналним везама које постоје међу људима и међусобној идентификацији чланова који имају сличан однос према вођи. Део либидиналних веза је усмерен са чланова групе на вођу, тако да се вођа позиционира (интројектује) у его идеалу сваког члана (вертикалне везе), а део либидиналних веза је усмерен на остале чланове групе, тако да долази до међусобне идентификације у егу (хоризонталне везе) (Freud, 1921). Идентификација са вођом се одвија кроз механизам уношења (интројекције) лика вође у психу појединца. Део психе у којем се процес идентификације одвија Фројд је испочетка називао еīo иgeaл, да би га касније назвао суйереīo. Стога се овај процес прецизније назива суйереīo иgенйификащија. Према оваквом тумачењу, чланови групе имају једнак однос према вођи и осталим члановима групе. Њихова различитост не долази до изражаја, па се губи и њихова индивидуалност. Група се види као побољшана и ојачана индивидуа (Szykierski, 2010). Ово је опис функционисања појединаца у маси налик приступу психологије масе, према којој појединац губи критичку свест у маси и постаје сугестиван на поруке које шаљу вођа и остали чланови групе.

Психоаналитичка концептуализација зрелог групног функционисања се појавила касније. Историјски гледано, интересантно је да су се дате концептуализације појавиле засноване на искуствима повезаним са Првим и Другим светским ратом. Аустријски аутор, психоаналитичар Ернест Крис (Ernst Kris) се бавио проблемима ратне пропаганде и припада еі̄o школи йсихоанализе, а британски психоаналитичар Вилфред Бион (Wilfred Bion) школи објекйних оgноса унутар психоанализе (Kris, 1943; Bion, 1961). Крис (1943) је први приказао два различита 
нивоа групног функционисања, регресивни и зрели, претпостављајући да у стварности постоји континуум између ова два облика и различити степени изражености датих нивоа.

У регресивном нивоу функционисања, група у потпуности прати комуникацију вође, а индивидуалне разлике не долазе до изражаја. Вођа се прихвата као его идеал и долази до идентификације у суперегу. У зрелом нивоу функционисања индивидуалне разлике долазе до изражаја. Порука вође је драж која изазива различите реакције код индивидуа. Различите реакције отварају могућност критике и неслагања. Идентификација се одвија у егу, јер се критичар може идентификовати са оним кога критикује. Ако повежемо ову теорију са савременим достигнућима у социјалној психологији, можемо рећи да зрели ниво функционисања групе омогућава појаву психолошке сигурности на радном месту, о којој смо претходно писали.

Бион (1961), слично Крису, разликује два нивоа групног функционисања: зрели и регресивни ниво. Приступ изучавању групног функционисања који Бион гради се може разумети у контексту историјског развоја психоаналитичке мисли и теорије, али у себи има и другачије елементе. Због значаја који Бион има за теорију групног функционисања посебно ћемо приказати специфичности његовог приступа, а затим и његову теорију према којој се зрели и регресивни ниво разликују као радна група и група основне претпоставке.

\section{Специфичности Бионовог приступа изучавању групног функционисања}

Сам Бион је приметио да је Фројд отворио нове могућности истраживања људске психе, захваљујући томе што је престао да проучава човека као изолованог појединца, већ се усредсредио на проучавање односа између двоје људи који се развија у психоаналитичкој ситуацији, посебно кроз феномен трансфера (преноса). Истраживање се преклапало са психотерапијом, јер су код Фројда долазили људи који су тражили помоћ због немогућности да сами изађу на крај са људском патњом или нису нашли помоћ нигде другде.

Теорија објектних односа Меланије Клајн (Melanie Klein), као измена и допуна Фројдове теорије, продубила је објашњење међусобних утицаја људи једних на друге, психолошким механизмима који су активни од најранијег периода људског развоја, као што је нпр. пројективна 
идентификација. Пре него што је постао психијатар и психоаналитичар, Бион је прошао искуство ратовања у Првом светском рату као официр тенкиста. Његово специфично искуство је допринело заузимању другачије позиције у проучавању групе, иако му је клајнијанска перспектива омогућила да препозна снажан утицај несвесних фантазија како на свесне идеје појединца, тако и на социјално понашање.

Бион (1961) сам позиционира своје размишљање као другачије у односу на постојеће психоаналитичке теорије, зато што полази од интерперсоналног социјалног аспекта наспрам дотадашњем интрапсихичком психолошком аспекту. Он јасно каже да га занима група као предмет истраживања, а не индивидуа у групи и посматра човека као члана групе, чак и када то није на први поглед видљиво. Појединац је увек члан групе, или, другим речима, политичко биће (зоон политикон). Бион говори о суштинској їруйльивосиии (енгл. groupishness) као неотуђивом квалитету човека као животиње стада. Због свеприсутне карактеристике да је човек животиња групе, нема потребе да се постулира инстинкт стада као објашњење посебних понашања.

Бион каже да је индивидуа, као животиња групе, у рату како са групом тако и са оним аспектима своје личности који чине његову їруйльи-

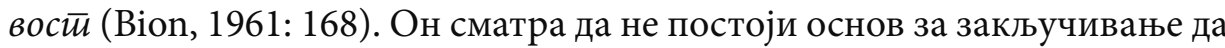
група представља више од збира њених чланова. Сакупљање појединаца је неопходно само ако желимо да учинимо видљивим одређене појаве, као што је трансферни однос, или да омогућимо члановима групе да буду очевици појава у групи на којима се заснивају интерпретације у раду са групом. Иначе, сједињавање групе на одређеном месту и у одређено време нема никаквог значаја за настанак групних појава, само за њихову демонстрацију и истраживање. Стога и привидна разлика између психологије групе и психологије индивидуе представља илузију подржану чињеницом да група истиче појаве које делују страно посматрачима који нису навикли да употребљавају групе у свом раду.

Мелцер разликује три периода Бионовог рада са групама, а сви су приказани у монографији Искустива у іруйама и осииали раgови (Meltzer, 1978). „Претходни осврт“ представља период његовог рада као војног психијатра у Другом светском рату, „Искуства у групам““ период када је радио као цивилни психијатар након рата, а „Накнадни осврт“ представља његова размишљања као психоаналитичара. Мелцер (1981) указује на значај војног искуства код Биона, карактеришући његов начин одговарања на директна питања у групи као „војну тактику“, тако што одговор креће супротно од очекиваног правца, кроз широки лук, као кад се непријатељу 
приближавамо страга, правећи досетке на само питање, да би на крају нашао место лаког пробоја оклопа језика којим је питање формулисано. Значај ратног искуства за Биона је видљив кроз публикације које је објавио, а представљају запис о сећањима из рата или коментаре на дата сећања. Дате публикације се објашњавају потребом за историзацијом трауме (Brown, 2007), а само искуство рата се посматра као врело будућих Бионових теоријских достигнућа (Szykierski, 2010).

Допринос Биона разумевању групне динамике је настао случајно, захваљујући томе што је био ангажован као војни психијатар у време Другог светског рата. Почетком 1942. постављен је у Одбор за селекцију Ратне канцеларије (Szykierski, 2008). Посебност Бионовог ангажмана се огледала у употреби властитог искуства из Првог светског рата и тражењу решења за проблеме које је требало решавати. Његова решења најчешће нису добро прихваћена и поред позитивних исхода примењених процедура. Први период Бионовог рада са групама, према Мелцеровој класификацији, поклапа се са три пројекта у којима је Бион био активан. Први је именовање кандидата за позицију официра, други селекција кандидата за тренинг за официре, а трећи је тзв. Нортфилд експеримент.

У првом пројекту Бион је у процедуру, која је тражила препоруке официра јединице, додао и препоруке изведене из чина у јединици и досијеа. На основу ове промене порастао је број препорука за $1500 \%$, негирајући тадашње уверење да постоји мањак вредних кандидата (Szykierski, 2008). У Савету Армије политички ешелон је посматрао пројекат као субверзиван, док га је војни ешелон одобравао због практичне користи.

Други пројекат је био повезан са развојем ефикасне процедуре за избор официра међу предложеним кандидатима. Дотадашња селекција је користила вредновање радног учинка на војним задацима, интервјуе и различите тестове. Бион је предложио процедуру која омогућава посматрање актуелног понашања канидидата који су стављени у ситуацију да се носе са групним задацима без формалног вођства (Trist, 1985). Бион (1946) објашњава да је циљ овакве процедуре ставити кандидате у ситуацију сличну ратној стварности, у којој нису они као појединци у жижи пажње већ група у целини. На тај начин личне амбиције за успехом и страхови од неуспеха бивају мање важни од одговора на питање да ли кандидат може бити пријатељ свом пријатељу тако да буде непријатељ свом непријатељу. После успеха овог пројекта очекивало се да ће Бион бити именован за водитеља пројекта, међутим, послат је у Центар за истраживања и обуку, након чега је тражио премештај за Нортфилд (Harrison, 2000). 
Психијатријска војна болница Нортфилд, близу Бирмингама, настала је преузимањем Холимур психијатријске болнице у ратне сврхе, прво 1939. у службу Хитне медицинске службе, а коначан назив је добила преласком у службу Ратне канцеларије априла 1942, због растућег броја психијатријских случајева (Harrison, 2000). Суштина приступа војне психијатрије је да се што више војника врати у службу у што краћем времену, и стога се пружање помоћи одвијало близу линије фронта. Међутим, замка коју војна психијатрија уводи је да војника који пати претвори у „болесника“ и на тај начин га ставља на размеђе две организационе културе, војног система који их одбацује као неспособне и медицинског система који их прихвата као болесне.

Бион и Рикман (John Rickman) су увели начин рада са групом који се показао успешан. Уместо да нагласак ставе на појединца у групи, они су нагласак ставили на групу у целини. Усмеравањем посматрања на појединца психијатар се ангажује у решавању неуротичних проблема и пружа сугестивне интервенције праћене подршком, док остали чланови групе учествују у катарзи захваљујући јавном признању. С друге стране, усмеравање посматрања на групу доводи до стицања знања и искуства о факторима који доприносе добром групном духу (Bion, 1961).

Уобичајени психијатријски начин рада је да се хоспитализовани пацијенти укључе у радну терапију која им окупира време, што наликује нивоу обданишта, како примећује Бион (1946). Промена коју је увео Бион састојала се у томе да се пред војнике постави захтев да се организују у групе око оних задатака око којих су се сами сложили. То је доводило у жижу пажње тензије које су настајале у сусрету са препрекама остварењу задатка. Усмеравањем војника на спољашњу реалност, пажња се удаљавала од беде присутне у унутрашњој реалности и помагала војницима да изађу из изолације и укључе се у истраживање себе. Захваљујући томе они су се снабдели искуством и знањем потребним за реинтеграцију у социјалне оквире, били они војни или цивилни (Szykierski, 2008).

Бион је третирао хоспитализоване војнике као особе способне да прихвате одговорност за свој живот и смрт. На тај начин је изашао из замке, с једне стране, војног модела који подстиче регресију на активну и дечју послушност, и с друге стране, медицинског модела који подстиче регресију на пасивно, бебеће слагање (Szykierski, 2008). Трист (1985) је то исказао рекавши да је Бион инсистирао на војној команди без медицинске контроле. Међутим, такав метод рада је учинио психијатра непотребним, јер су групним радом могли управљати људи различитих професија, 
а дијада пацијент-доктор и концепти болести и лечења нису били потребни. Да ли због тих или неких других разлога, рад Биона и Рикмана прекинут је након шест недеља. Бион (1961) се касније присећа да су га пацијенти упозоравали на озбиљне покушаје саботирања њиховог приступа.

Суштина Бионовог приступа је у питајућем ставу и техници посматрања понашања индивидуе у оквиру групе. На тај начин се долази до информација које нису под утицајем приче пацијената или очекивања особља. Биону је усмеравање пажње на социјалне односе омогућило да види, с једне стране, однос система према војнику као објекту манипулације, и с друге стране, однос војника према систему као објекту пројекције. Захваљујући питајућем ставу Бион није прихватао да решава проблеме за групу, већ је инсистирао на истраживању од стране групе, захтевајући да се том послу приступи са научном озбиљношћу (Bion, 1961). Зикиерски (Szykierski, 2008) се пита да ли Бионов питајући став, камен темељац теорије и технике развијене касније на Тависток клиници, и даље представља превелику претњу, као да је незамисливо да довођење у сумњу или постављање питања може бити довољна интервенција да се група мотивише на решавање проблема. Сам Бион (1961) је приметио да се из искуства са групама најбоље види ужас са којим се питајући став посматра.

\section{Радна група и групе основне претпоставке}

Бион је поставио критеријум на основу којег се посматра функционисање групе. Он каже да је група дефинисана задатком који је држи на окупу до његовог извршења. Таква група се назива раgна їруйа. Каже се да радна група функционише на зрелом нивоу зато што ради на задатку, има добар однос према реалности, а комуникација међу члановима је логична и јасна (Shapiro, 1991). Функционисање групе се заснива на свесно мотивисаном понашању усмереном на остварење задатка у реалности. Биона, пре свега, занима функционисање групе у целини, односно мисаона активност људи у групи. Да би група радила потребна је добровољна сарадња и одређени ниво софистицираних вештина који омогућава рационалан приступ близак научном (Bion, 1961). Ако све иде како треба, радна група функционише на зрелом или софистицираном нивоу.

Међутим, ниједна група не функционише искључиво на свесном нивоу, јер је несвесно увек укључено у функционисање појединаца и група. Биону је клајнијанска перспектива омогућила да препозна сна- 
жан утицај несвесне фантазије на свесне идеје и социјално понашање (Szykierski, 2010). Он претпоставља да појединац користи примитивне облике психичког функционисања у групи, што је последица тешкоћа са којима се одрастао човек сусреће када треба да оствари контакт са емотивним животом групе којој припада. Бион каже да је та тешкоћа упоредива са сложеношћу ситуације пред којом се налази беба када треба да успостави контакт са телом мајке (Bion, 1961). Немогућност да се носи са емотивним животом групе доводи човека до регресије, у оквиру које се јавља веровање да група постоји као нешто различито од скупа индивидуа, тј. активира се фантазија да група постоји као организам идентичан индивидуи, односно мајци, гледано из перспективе бебе.

Наспрам софистицираном нивоу функционисања постоји и примитивни ниво функционисања, који Бион назива функционисане у склаgy са основним йретийосйавкама. Реч је о душевним активностима са снажним емотивним набојем, које ометају, преусмеравају, а некад и помажу активности радне групе (Bion, 1961). Дате активности се објашњавају несвесним механизмима који се покрећу код чланова групе и доводе до понашања које не води рачуна о реалности, логици и времену, већ је усмерено несвесним жељама и фантазијама. Доима се да је група окупљена из сасвим другог разлога него што је остварење постављеног задатка у реалности. Чланови групе су често уједињени прикривеним претпоставкама заснованим на несвесним фантазијама (Shapiro, 1991). Бион је препознао три опште категорије основних претпоставки: зависност, борба/бежање, упаривање. Оне представљају манифестацију инстинктуалних жеља и нагона везаних за приврженост, агресивност и сексуалност (Erlich, 2001).

Учешће у активностима основне претпоставке је неизбежно, тренутно и инстинктивно, оно не захтева никакво искуство, учење или развој. Свака особа има „валенцију“ као способност за тренутну невољну комбинацију са другим особама приликом активирања у складу са основном претпоставком (Bion, 1961). Валенца или афинитет појединца за одређену основну претпоставку је аспект индивидуе који тражи и покреће чланство у групи (Shapiro, 1991).

Оба нивоа функционисања, примитивни и софистицирани, важни су за развој. Функција радне групе је рационално сналажење са задацима у реалности, док је функција групе основне претпоставке несвесна одбрамбена активност која управља анксиозностима како не би нарушиле однос према реалности (Szykierski, 2010). Употребом основне претпоставке рационализују се искуства која провоцирају анксиозност. 
Кад доминира основна претпоставка зависност, група се окупља да би била подржана од вође од којег зависи у погледу материјалне и духовне исхране и заштите. Кад доминира основна претпоставка борба/бежање, убеђивањем да постоји непријатељ рационализују се осећања беса и мржње. Кад доминира основна претпоставка упаривање, такво понашање се рационализује потребом за репродукцијом кроз сексуалност.

Посматрајући функционисање радне групе, Бион је уочио да главна група издваја специјализовану радну групу која има задатак да ради на основним претпоставкама како исте не би ометале рад главне групе. Функција специјализоване радне групе је да спречи изражавање основне претпоставке без медијације разложности (Szykierski, 2010). Главна и специјализована радна група имају обрнут правац акције. Радна група преводи мисли и осећања у понашања прилагођена реалности. Претварање основних претпоставки у понашања би било опасно, и стога је задатак специјализоване радне групе обрнут, активности се преводе у појмове карактеристичне за менталитет основне претпоставке. Примери специјализованих радних група у свету су: црква (зависност - јачање религијских уверења), војска (борба/бежање - јачање силе), аристократија (упаривање - јачање наде у рођење наследника).

\section{Вођство у групама: основне претпоставке}

Могло би се рећи да су промене у понашању код чланова групе, које се крећу из радне мотивације у мотивацију која произилази из основне претпоставке, повезане са карактеристикама вођства (Shapiro, 1991). Функција вођства у радној групи је одређивање задатка. Он може бити јасно и прецизно постављен, а некад је имплицитан, подразумевајући. С обзиром да у свакој радној групи делују и основне претпоставке, дата ситуација се одражава на појединце и долази до изражаја у сукобу ставова према вођама радне групе и вођама групе основне претпоставке.

Бион се није сложио са Фројдовим гледањем на вођство и истакао је да Фројд није јасно показао опасности које леже у појави вођства (Bion, 1961). Бион каже да вођа радне групе бар носи заслугу што има контакт са спољашњом реалношћу, док се тако нешто не може рећи за вођу групе основне претпоставке. Није сматрао да особеност појединца постоји одвојено од његове/њене позиције у групи (Szykierski, 2010), него да вођу држе иста „веровања“ као и остале чланове групе, јер су 
ставови вође и ставови чланова групе подједнако последица деловања основне претпоставке. Објашњавајући разлику између свог и Фројдовог гледишта, Бион каже да је Фројд у тумачењу појаве поистовећивања чланова са вођом користио само појам интројекције (уношења, односно преузимања особина вође као властитих), док он то посматра и кроз процес пројективне идентификације (где члан групе прво пројектује или преноси на вођу одређене властите особине да би се накнадно са њима поистоветио).

Механизам пројективне идентификације се може применити и шире, не само за разумевање односа чланова групе према вођи, већ и за разумевање динамике различитих улога које се јављају у групи, па и вође групе основне претпоставке. Чланство у групи иначе делује на слабљење граница личности међу члановима, тако да се особине личности лако приписују другим члановима групе. Механизам пројекције јача тенденцију код изабраног појединца да прихвати улогу која му се додељује, а накнадне пројекције утичу на учвршћивање позиције појединца у датој улози. Тако долази до појаве вође групе основне претпоставке. Вођа такве групе може довести своје понашање унутар улоге до екстрема, са учешћем веома снажних емоција и остављајући утисак бизарног и нестварног (Shapiro, 1991).

На радне групе позитивно делује када се динамика придавања вођства члану групе односи на тренутног вођу, јер онда он у својој радној улози добија и подршку која долази од групе основне претпоставке. Међутим, ако је динамика групе таква да води у регресију, онда се појављује вођа основне претпоставке у другој личности и вођу радне групе оставља немоћног да води групу ка постављеним циљевима. Чланови групе са ентузијазмом прихватају новог вођу, али такав вођа нема контакт са реалношћу и не може водити групу никаквом конструктивном решењу. Он само учествује, заједно са осталим члановима групе, у понашању које проистиче из дејства основне претпоставке.

\section{Ефекти регресије у групи и организацији на корпоративну безбедност}

Из претходне дискусије произилази да је за корпоративну безбедност важно да постоји функционисање у оквиру организације засновано на сарадњи, одржавању контакта са реалношћу, мотивацији која проистиче првенствено из домена радне групе, а подржана је и мотивацијом групе основне претпоставке. При том подразумевамо да су улоге пра- 
вилно расподељене и да се сваки појединац адекватно понаша унутар своје радне улоге. За руководиоце људским ресурсима, гледано из угла корпоративне безбедности, важно је да пажњу, пре свега, усмеравају на групну динамику и индикаторе функционисања групе. При том треба мењати угао гледања због сложености организације, јер се може посматрати унутаргрупно функционисање и међугрупно функционисање. Основни индикатори функционисања су сарадња, одржавање контакта са реалношћу, отвореност у изношењу мишљења, мотивација усмерена на остварење задатка.

Када руководиоци људским ресурсима уоче пад по набројаним критеријумима, може се претпоставити да је дошло до дејства основне претпоставке која нарушава функционисање радне групе. Последице такве промене се директно одражавају на безбедносну културу организације и видљиве су у свим њеним компонентама (Станаревић, Гачић и Јаковљевић, 2012). Ако посматрамо појединачно компоненте безбедносне културе (култура информисања, култура поверења, култура пријављивања, култура учења и култура прилагођавања; према Milanović i Radovanović, 2015), можемо да претпоставимо да ће процеси прикупљања и анализе података релевантних за безбедности бити заустављени или искривљени, пријављивање непотпуно, могућност непромишљеног деловања и неоправданог преузимања ризика повећана, учење на грешкама прекинуто, а прилагођавање преусмерено на понашање у складу са основном претпоставком уз губитак контакта са реалношћу. Даље последице се могу манифестовати у одливу информација, слабљењу међугрупне сарадње, паду продуктивности, паду свести о безбедности и слично.

Озбиљност последица на организациону и безбедносну културу, те укупно функционисање организације, услед регресије у групи и организацији, налаже озбиљне мере предострожности усмерене на праћење унутаргрупне и међугрупне динамике. При том треба имати у виду да и мониторингом социјалних појава управљају они исти људи који могу да се нађу под негативним утицајем основне претпоставке. Стога је уобичајена пракса да организације користе спољне саветнике у решавању проблема у вези са људским ресурсима. Спољни саветници нису под утицајем групне динамике у организацији, долазе са јасним задатком и поседују компетенције потребне за саветодавни рад. Иако су релативно заштићени од дејства основне претпоставке присутне у групама у организацији, и саветници постају објект пројективне идентификације уласком у организацију. Њихов задатак није ни лак ни једноставан, али је често неопходан у подстицању позитивних промена у организацији. 


\section{Закључак}

Корпоративна безбедност, широко схваћена, усмерена је на било коју акцију која може бити одговор на штету која може настати по организацију/корпорацију. Кад се помињу људски ресурси као фактор корпоративне безбедности, често се о њима говори у оквиру појмова организационе и безбедносне културе, или, гледано из угла појединца, кроз пожељне особине личности и изградњу свести о безбедности. Посматрано из аспекта међуљудских односа, важна је изградња психолошке сигурности на радном месту и културе отвореног изражавања мишљења. У овом раду смо усмерили пажњу на појаву регресије у групи и организацији. Употребом Бионове теорије о групама увели смо разликовање два функционисања групе, као радне групе и као групе основне претпоставке. Издвојили смо индикаторе који разликују ове облике функционисања, а то су: сарадња, одржавање контакта са реалношћу, отвореност у изношењу мишљења, мотивација усмерена на остварење задатка. Уколико су набројани индикатори присутни, имамо посла са функционисањем радне групе, а уколико нису постоји сумња на дејство групе основне претпоставке. Ефекти регресије у групама и организацијама на корпоративну безбедност су веома негативни и стога је познавање ове појаве важно за правовремено препознавање и спречавање њеног развоја, као и за интервенисање у поновно улагање у функционисање радне групе. 


\section{ЛИТЕРАТУРА}

Bion, W. R. (1946). 'The leaderless group project'. Bulletin of the Menninger Clinic, 10(3), 77-81.

Bion, W. R. (1961). Experiences in Groups and Other Papers. London: Tavistock.

Brooks, D. (2013). Corporate Security: Using Knowledge Categorization to Define a Practicing Body of Knowledge. Asian Journal of Criminology, 8(2), 89-101.

Cross, R., Rebele, R., \& Grant, A. (2016). Collaborative Overload. Harvard Business Review, 94(1), 74-79.

Dalton, D. (2003). Rethinking Corporate Security in the Post 9/11 Era. Boston: Butterworth-Heinemann.

Edmondson, A. C. (2018). The Fearless Organization: Creating Psychological Safety in the Workplace for Learning, Innovation, and Growth. Hoboken, NJ: John Wiley \& Sons Inc.

Erlich, H. S. (2001). The Elusive Subject and the Psychoanalytic Study of Organizations. Organizational \& Social Dynamics, 1(2), 199-211.

Freud, S. (1921). Group Psychology and the Analysis of the Ego. London: Hogarth.

Gallup. (2012). State of the American Workplace Report. Washington: Gallup. Gallup. (2017). State of the American Workplace Report. Washington: Gallup. Harrison, T. (2000) Bion, Rickman, Foulkes and the Northfield Experiments: Advancing on a Different Front. London: Jessica Kingsley.

Kordić, B. (2017). Uvod u socijalnu psihologiju. Beograd: Centar za primenjenu psihologiju.

Kris, E. (1943). Some problems of war propaganda: a note on propaganda new and old. In The Selected Papers of Ernst Kris (1975) (pp. 433-450). New Haven, Conn.: Yale. Univ. Press.

Meltzer, D. (1978). The Kleinian Development. London: Karnac.

Meltzer, D. (1981). Memorial meeting for Dr. Wilfred Bion held by the British Psycho-Analytical Society on 20 February 1980. International Review of Psycho-Analysis, 8, 3-14.

Milanović, Z. i Radovanović, R. (2015). Informaciono-bezbednosna kultura - imperativ savremenog društva. Nauka, bezbednost, policija, 20, 45-65.

Power, M. (2007). Organized Uncertainty: Designing a World of Risk Management. Oxford: Oxford University Press.

Schneider, J. A. (2015). Bion's Thinking about Groups: A Study of Influence and Originality. Psychoanalytic Quarterly, 84(2), 415-440.

Shapiro, R. L. (1991). Psychoanalytic Theory of Groups and Organizations. Journal of the American Psychoanalytic Association, 39, 759-781. 
Станаревић, С., Гачић, Ј. и Јаковљевић, В. (2012). Интегрисање концепта safety и security културе у корпоративну безбедност. Гоgишғак

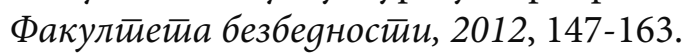

Szykierski, D. (2008). The Northfield Experiment and the Enigma of Psychiatry without Psychiatrists. Organizational \& Social Dynamics, 8(1), 38-62.

Szykierski, D. (2010). Shaping the Group Relations' Discourse: Bion's Position regarding Freud's View on Groups. Organizational \& Social Dynamics, 10(1), 56-78.

Szykierski, D. (2010). The Traumatic Roots of Containment: The Evolution of Bion's Metapsychology. Psychoanalytic Quarterly, 79(4), 935-968.

Trist, E. (1985). Working with Bion in the 1940s: the group decade. In M. Pines (Ed.), Bion and Group Psychotherapy (pp. 1-46). London: Tavistock/ Routledge.

Walby, K., \& Lippert, R. K. (2014). Introduction: Governing Every Person, Place, and Thing - Critical Studies of Corporate Security. In K. Walby \& R. K. Lippert (Eds.), Corporate Security in the 21st Century: Theory and Practice in International Perspective (pp. 1-13). Hampshire: Palgrave Macmillan. 


\title{
GROUP AND ORGANIZATION REGRESSION AND CORPORATE SECURITY
}

\author{
Boris Kordić, Full Professor \\ University of Belgrade, Faculty of Security Studies
}

\begin{abstract}
Summary
This paper examines the occurrence of a group and organization regression by using Bion's group theory that distinguishes two forms of group functioning, as a work group and as a basic assumption group. The effects of a group and organization regression on corporate security are very negative and, therefore, knowledge of this phenomenon is important for the timely recognition and prevention of its development, as well as for intervention in reinvestment in the functioning of the working group. By looking more closely at the specificity and context in which Bion's theory originated, and the basic tenets of the theory, we came to indicators that differentiate between these forms of group functioning, namely: cooperation, maintaining contact with reality, openness in speaking up opinions, task motivation. If the listed indicators are present, we are dealing with the functioning of the working group, and if there is a doubt that the basic assumptions group is active.
\end{abstract}

Keywords: group regression, group cooperation, working group, basic assumption group. 